\title{
Adat Turun Tanah Bagi Suku Jawa Di Kota Palangka Raya Ditinjau Dari Prespektif Islam
}

\author{
Miftahul \\ IAIN Palangka Raya \\ miftahul223@gmail.com
}

\begin{abstract}
This study took place in the city of. This research is a custom object off the ground for Javanese conducted by the public in Palangkaraya. The approach used is descripive qualitative data collection techniques such as interviews, observation, and documentation. Validation data using triangulation techniques and to analyze the data through several stages, namely: data collection (Data Collettion), data reduction (Data Reduction), data presebtation (Data Display), and then the new conclusion (Conclusions Data) by looking back at the data that has been collected. The results showed that the customary land down since time immemorial have been made of their ancestors and continue to this day, they are considered custom picture off the ground known as the child's talents or interests that relate man to God Almighty to always tangible safety, protection, peace, and prosperity in life. Furthermore, the results of the analysis of the study stated that the customs off the ground in the city of Palangkaraya nothing that violates the Islamic law. So if there are irregularities in the implementation of the Islamic law, then they should not be implemented custom not to be involved in the case shirk.
\end{abstract}

Keyword : Indigenous, islamic law perspective and parts java

\section{A. Pendahuluan}

Setiap daerah pada dasarnya memiliki kebudayaan yang ingin dilestarikan karena merupakan peninggalan kebudayaan yang memiliki ciri khas dan identitas dari tiap-tiap daerahnya tersebut. Namun, tidak sedikit dari masyarakat mengenal dan memahami pelaksanaan tradisi-tradisi mereka.Ketika masyarakat yang akan melakukan adat kebiasaan sebaiknya sesuai dengan hukum yang berlaku, namun dibalik semua hukum atau ketetapan dalam adat kebiasaan yang dilakukan masyarakat diberi kemudahan karena ritual ini dilakukan sekali seumur hidup. Masyarakat umumnya melaksanakan adat kebiasaan tersebut dikarenakan sudah menjadi suatu kebiasaan yang lazim dilaksanakan. Ketika salah satu dari anggota masyarakat meninggalkan adat 
istiadat tersebut, maka masyarakat dianggap tidak menghormati para leluhur mereka yang telah membangun adat tersebut sejak lama.

Perkara-perkara adat kebiasaan yang dilakukan oleh manusia dalam setiap hari bisa mempunyai karakter yang berbeda-beda sesuai dengan niat dan tujuannya. Jika perbuatan-perbuatan tersebut didorong oleh ketakwaan atau taat kepada perintah Allah, maka hal itu dianggap sebagai ibadah. Namun jika tidak didorong oleh niat yang sedemikian, maka ia tidak dianggap sebagai ibadah dan tidak berpahala. Sebagaimana yang dikatakan oleh Imam ar-Ramli, orang yang melakukan perbuatan dan adat kebiasaan hendaklah menyatakan dan menghadirkan niatnya itu supaya dia mendapatkan pahala ibadah. Bahkan, akan terasa nikmat dan disenangi oleh jiwa. ${ }^{1}$

Masyarakat suku jawa merupakan salah satu bagian dari bangsa Indonesia yang mempunyai budaya khas termasuk didalamnya cara pandang hidup dan hal-hal yang terkait dengan anak. Dengan memperhatikan pendidikan anak hingga dewasa merupakan tanggung jawab untuk menyediakan bekal dalam menjalani hidup.Maka kedua orang tua mempunyai kewajiban untuk memberikan pendidikan kepada anak- anaknya, karena baik buruknya anak tergantung dari pendidikan kedua orang tua.

Rasulullah Saw. bersabda:

"Telah menceritakan kepada kami Yazid bin Harun, ia berkata: telahmenceritakan Amir bin Sholih bin Rustam Muzani, telah menceritakan kepada kami Ayyub bin Musa bin Amri bin Said bin Ash berkata: Aw bin Ash dari ayahnya, dari kakeknya berkata: bahwa Rasulullah SAW bersabda: "Tidak lebih utama pemberian orangtua terhadap anaknya dibanding (pemberian) adab (pendidikan) yang baik”.

Berdasarkan hadis di atas, bahwa kedua orang tua si anak diwajibkan memberi pendidikan hingga mencapai dewasa untuk si anak dapat bertanggung jawab dalam menjalani hidup. Apabila kedua orang tuanya tidak bisa

${ }^{1}$ Wahbah az-Zuhaili, Fiqih Islam Wa Adillatuhu Jilid 1, (Jakarta: Gema Insani, 2010), hal. 192. 
memberikan pendidikan sendiri, maka sebaiknya diserahkan pada para pengajar untuk memberikan pendidikan sebaik-baiknya. ${ }^{2}$

Aktivitas masyarakat Jawa pada dasarnya kental dan peka terhadap tata cara adat istiadat. Namun, berbeda dengan masyarakat Jawa yang ada di perantauan. Kekentalan masyarakat Jawa terhadap adat istiadat adalah memahami bahwa tata cara adat istiadat mereka mengandung do'a-do'a dan harapan orangtua, keluarga, dan masyarakat. Namun, upacara adat istiadat hanya dilaksanakan pada bagian hidup manusia yang dianggap penting.

Setiap masyarakat daerah mempunyai adat kebiasaan yang sudah menjadi ciri khas dari setiap daerah. Banyak sekali adat kebiasaan yang terdapat di setiap daerah dan memiliki perbedaan di kota besar. Salah satu adat istiadat yang masih dilakukan hingga saat ini oleh masyarakat Jawa yaitu, adat Turun Tanah yang terletak di Kota Palangka Raya. Menurut Ani Rostiyati bahwa adat turun tanah banyak dilaksanakan di desa-desa seperti daerah di Desa Gadingharjo kelurahan Pringgokusuman kecamatan Gedongtengen kotamadya Yogyakarta propinsi Daerah Istimewa Yogyakarta. ${ }^{3}$ Desa ini memiliki tradisi adat istiadat yang dipegang teguh dan dilestarikan secara turuntemurun sebagai budaya. Setelah bayi lahir ada beberapa bentuk upacara ritual yang harus dilakukan ketika melangsungkan acara yangberlangsung mulai dari brokohan ${ }^{4}$ sepasaran, ${ }^{5}$ selapanan, ${ }^{6}$ nyapih, ${ }^{7}$ netoni (weton anak), ${ }^{8}$

${ }^{2}$ M. Aftan Chafidh dan A. Ma'ruf Asrori, Tradisi Islam (Panduan Prosesi Kelahiran- Perkawinan-Kematian), (Surabaya: Khalista, 2006), hal. 71-72.

${ }^{3}$ Ani Rosyanti dkk, Fungsi Upacara Tradisional Bagi Masyarakat Pendukungnya Masa Kini, (Yogyakarta: Departemen Pendidikan dan Kebudayaan, 1994), hal. 23.

${ }^{4}$ Brokohan adalah selamatan bayi berusia satu hari.

${ }^{5}$ Sepasaran adalah selamatan upacara adat bagi bayi yang berumur lima hari.

${ }^{6}$ Selapanan adalah selamatan peringatan hari kelahiran dalam tiga puluh lima hari. sekaligus.

${ }^{7}$ Nyapih adalah selamatan proses berhentinya masa menyusui secara berangsur-angsur atau

${ }^{8}$ Netoni (weton anak) adalah selamatan yang diadakan bertepatan pada hari dan pasar an kelahiran si anak. 
tedhak siten, gaulan, ${ }^{9}$ penanaman ari-ari, nyetahuni, ${ }^{10}$ dan khitanan/tetesan. Jika ritual-ritual ini dilaksanakan maka dapat memberikan gambaran kehidupan yang berhubungan dengan manusia dan Allah SWT yang dilandaskan agar senantiasa diberikan wujud keselamatan, perlindungan, ketentraman, dan kesejahteraan dalam hidup.

Adat turun tanah sering disebut masyarakat Jawa dengan upacara Tedhak Siten yang telah memahami tata cara adat turun tanah, dan hingga sekarang masih sering dilaksanakan bagi masyarakat Jawa di daerah asalnya.

Turun tanah adalah memperkenalkan anak untuk pertama kalinya menginjak tanah atau bumi. Tradisi ini biasanya dilaksanakan ketika anak berusia 7 bulan atau lebih serta si anak tersebut siap untuk melaksanakan turun tanah. Upacara turun tanah ini menggunakan perlengkapan yang terbuat dari kurungan ayam (kandang ayam).

Masyarakat Kota Palangka Raya sendiri sebagian besar banyak sekali berbagai jenis suku yang termasuk suku Jawa. Masyarakat Jawa hanya terdapat beberapa orang saja yang telah melaksanakan adat istiadat kebiasaan, sebab cuma orang-orang tertentu saja yang hanya mengetahui adat kebiasaan tersebut dalam melaksanakan kehidupan bermasyarakat. Walaupun tetap diupayakan untuk dilaksanakan, mengingat bahwa berbagai macam adat kebiasaan sudah menjadi turun temurun dilakukan oleh masyarakat Jawa. Masyarakat Jawa juga melaksanakan adat kebiasaan ini untuk meminta keselamatan dan rasa syukur kepada Allah SWT ketika acara adat berlangsung dan khususnya bagi si anak ketika mengarungi kehidupan dalam masyarakat. Tradisi ini sebagai faktor terwujudnya untuk mencapai kebahagian sang anak kelak yang dihubungkan dengan berbagai ritual dan simbol-simbol. Hal inilah yang mendorong peneliti tertarik melakukan penelitian tentang adat turun

${ }^{9}$ Gaulan adalah selamatan yang dilakukan pada saat si anak mulai tumbuh gigi untuk pertama kalinya

${ }^{10}$ Nyetahuni adalah selamatan bayi berusia satu tahun. 
tanah bagi suku Jawa ini, dimana pada dasarnya setiap daerah tidak jarang sekali masyarakat yang mengetahui berbagai macam tradisi-tradisi adat dari nenek moyang terdahulu yang menjadi suatu kebiasaan yang dilakukan dalam kehidupan bermasyarakat. Sehingga setiap dalam kehidupan masyarakat telah melaksanakan berbagai adat istiadat sebagai lambang untuk menjalankan hidup bermasyarakat sekitar yang sudah berlangsung dari generasi ke generasi.

Adat kebiasaan akan dianggap sebagai hukum apabila kebiasaan tersebut tidak bertentangan dengan syariat Islam dan dapat diterima oleh semua pihak tanpa ada pertentangan mengenai hal tersebut. Apabila dalam adat turun tanah ini terdapat hal-hal yang dapat merubah keyakinan, maka tradisi tersebut tidak dapat dibenarkan dalam Islam. Walaupun begitu banyak sekali kebiasaan yang dapat diterima, namun bisa terjadi ketidaksesuaian dengan syara'.

\section{B. Kajian Pustaka}

Dalam perkembangan tata kehidupan masyarakat Kota Palangka Raya berdasarkan pengalaman mereka tentang keberadaan adat turun tanah dapat dijadikan sebuah keyakinan yang mengarah kepada suatu wujud keselamatan, perlindungan, ketentraman, dan kesejahteraan dalam menjalankan kehidupan bermasyarakat. Hal ini merupakan kepercayaan mereka bahwa perjalanan hidup setiap orang memiliki beberapa tahap. Sedangkan tahap-tahap kehidupan itu sendiri mempunyai saat kritis yang menjadi dasar sekaligus menentukan proses kehidupan pada tahap berikutnya. Turun tanah adalah suatu acara adat bagi sang anak yang baru mulai berjalan atau menapakkan kaki ke tanah untuk diperkenalkan pertama kali pada bumi atau tanah dengan maksud sang anak tersebut mampu berdiri sendiri dalam menempuh kehidupan kelak.Turun tanah juga sebagai bentuk pengharapan orang tua terhadap buah hatinya agar sianak kelak siap dan sukses menampaki kehidupan yang penuh dengan rintangan danhambatan dengan bimbingan orang tuanya.Ritual ini 
sekaligus sebagai wujudpenghormatan terhadap siti (bumi) yang memberi banyak hal dalam kehidupan manusia. ${ }^{11}$

Adapun dalam masyarakat Kota Palangka Raya sendiri turun tanah adalah suatu tradisi yang dilakukan kepada sang anak untuk pertama kali menginjakkan tanah yang guna memperkenalkan sang anak pada bumi atau dunia nyata. Masyarakat Kota Palangka Rayasendiri terdiri dari berbagai penganut agama yang berlainan yaitu beragama Islam174.638 orang, Kristen 73.968 orang, Katolik 4.609 orang, Hindu 4.104 orang, Budha 447 orang, Konghucu 20 orang, dan Aliran Kepercayaan 2.350 orang serta sangat mempercayai adat istiadat yang dibawa oleh nenek moyang mereka yang diturunkan secara turun temurun. Hingga saat ini pun mereka tetap mempertahankan dan menjaga adat tersebut termasuk adat turun tanah bagi suku Jawa di Kota Palangka Raya. Namun kehidupan masyarakat Kota Palangka Rayasendiri sangat menjunjung tinggi nilai budaya dan salah satu budaya yang dianggap penting.

Dalam kehidupan masyarakat Kota Palangka Raya adat turun tanah ini merupakan salah satu dari jenis budaya yangdilakukan oleh masyarakat Kota Palangka Raya bukan hanya untuk menjaga kelestarian adat istiadat, namun juga merupakan suatu kebiasaan turun-temurun dari nenek moyang sehingga menjadi budaya yang didasari dengan penyatuan kepada alam semesta tersebut, hal ini seperti yang diungkapkan oleh informan SR dan AD di atas. Adat turun tanah merupakan suatu cara tradisi peninggalan nenek moyang masyarakat Jawa yang semulanya masih menganut ajaran agama Hindu, setelah kemudian memeluk agama Islam ketanah ini.Karena itu adat turun tanah anak tidak bisa lepas dari sejarah masuknya Islam ke daerah Kalimantan Tengah khususnya. Setelah Islam masuk dan berkembang, akhirnya upacara adat tersebut bisa diIslamisasikan. Sehingga sebelumnya adat ini diisi dengan bacaan

${ }^{11}$ Lihat Henki Wisnu Subakti, dalam http://www.scribd.com/doc/29323674/Sejarah (Online 29 November 2011). 
menggunakan mantra-mantra dan pujaan kepada Dewa-dewa yang telah dipercayai oleh nenek moyang terdahulu, maka akhirnya pemujaan terhadap Dewa-dewa dan mantra digantikan dengan membaca zikir dan do'a-do'a yang berbasis keIslaman Turun tanah sendiri merupakan tradisi kuno yang keberlangsungannya sampai sekarang dipengaruhi oleh perpaduankepercayaan terhadap nenek moyang mereka. Melalui turun tanah inimenjadisebuah tradisi dan adat istiadat yang mulai berkembang pelaksanaannya. Sehingga dalam pelaksanaannya pun terlihat diwarnaidengan nuansa nilai-nilai keIslaman.

\section{Metodologi Penelitian}

Pendekatan yang digunakan penulis dalam penelitian ini adalah kualitatif deskriptif, dengan menggunakan pendekatan kualitatif deskriptif merupakan metode atau cara untuk mengadakan penelitian seperti halnya penelitian non-eksperimen yang dari segi tujuannya akan diperoleh jenis atau tipe yang diambil. Pendekatan ini akan menghasilkan data deskriptif yaitu berusaha mengerti dan memahami suatu.

\section{Pembahasan}

Pada dasarnya setiap perbuatan yang dilakukan oleh manusia memiliki makna dan manfaat untuk melakukan sebuah perbuatan atau tindakan yang akan dilaksanakan dan dipatuhi, begitu juga seperti kepatuhan masyarakat Kota Palangka Raya terhadap adat turun tanah yang berdasarkan hasil wawancara dan observasi terhadap subyek penelitian maupun informan penelitian, diperoleh 2 (dua) faktor yang mempengaruhi hal-hal tersebut antara lain: Tempat tinggal adalah suatu tempat yang akan ditinggali oleh anggota keluarga yang terdiri dari kepala keluarga, suami isteri, dan anggota keluarga lainnya. Setiap anggota keluarga ada beberapa orang saja yang melakukan perantauan ke kota-kota lainnya untuk memenuhi kebutuhan dalam melengkapi hidup bermasyarakat misalnya dalam acara pelaksanaan adat istiadat setempat. 
Berdasarkan penjelasan di atas, bahwa masyarakat Kota Palangka Raya merupakan suatu masyarakat perantauan yang berasal dari Jawa pergi ke Palangka Raya yang menjadi tempat tinggal mereka. Sehingga masyarakatyang perantauan bertempat tinggal yang semakin maju dan memiliki pemikiran yang semakin modern membuat kentalnya adat makin berkurang dari aslinya tapi masyarakat tetap melakukannya walaupun adat tersebut kurang perlengkapan dalam acara tersebut. Pembiayaan disini adalah suatu pembiayaan yang dikeluarkan oleh pihak yang akan melaksanakan acara turun tanah tersebut. Sehingga dalam acara tersebut memerlukan biaya yang banyak apabila ingin mengadakan pelaksanaan yang lengkap, dan bagi masyarakat yang kurang mampu tentunya akan sulit. Prosesi PelaksanaanAdat Turun Tanah Bagi Suku Jawa di Kota Palangka Raya. Dalam pelaksanakan adat turun tanah ini biasanya dilakukan sekitar depan halaman di rumahsendiriatau di tempat tinggal pihak keluarga yang melaksanakan adat,jika dilakukan di rumah sendiri maka dapat mengundang para tetangga maupun kerabat dekat untuk menghadiri acara tersebut.Tradisi ini biasa dilaksanakan kapan pun dan tidak menentu waktunya kalau si pihak keluarga benar-benar sudah siap dalam melaksanakan adat tersebut, sehingga masyarakat Jawa dapat saling beramai-ramai berkumpul dan juga menjalin sillahturahmi satu sama lainnya.

Berdasarkan hasil wawancara yang didapatkan penulis masyarakat Kota Palangka Rayadalam mengadakan acara adat turun tanah agar si anak lakilaki atau perempuan tersebut nantinya tidak mendapatkan kesusahan, rintangan, dan hambatan dalam menjalankan kehidupan kelak dan agar si anak yang bersangkutan nanti mampu berdiri sendiri dalam menempuh kehidupan yang penuh tantanganketika mereka dewasa seperti disampaikan oleh masyarakat setempat sehingga apabila mengerjakannya orang tua sang anak berharap akan dapat menghindari si anak dari bentuk gangguan kejahatan dan perbuatan buruk di dunia. Adat turun tanah dilaksanakan dirumah warga 
yang mempunyai anak perempuan atau laki-laki yang akan diturun tanah, dalam mempersiapkan dan menentukan acara ini maka ditentukan oleh pihak yang penyelenggara atau sesepuh yang diminta oleh orang tua si anak sebelumnya. Setelah itu orang tua sang anak mempersiapkan perlengkapan apa saja yang perlu dipersiapkan dalam melaksanakan acara turun tanah ini dan orang tua sang anak dapat mengundang para tetangga dan kerabat dekat untuk hadir pada acara tersebut.

Pelaksanaan adat turun tanah dalam masyarakat Kota Palangka Raya ini dilaksanakan ketika anak minimal berumur 7tahun atau 8 tahun lebih sedikit.Adapun waktu pelaksanaan dilakukan pada pagi hari.Sedangkan mengenai hari tidak menentu boleh kapan saja. Pemimpin yang terpenting dalam pelaksanaan adat turun tanah ini adalah sesepuh atau orang yang memimpin hingga awal sampai akhir acara dengan didampingi oleh kedua orang tua sang anak yang akan diturun tanah agar acara tersebut dapat berjalan dengan lancar dan sukses sesuai yang diinginkan dalam menempuh kehidupan bermasyarakat. Selanjutnya, didalam adat turun tanah ini juga membaca zikir dan do'a-do'a bersama yang berisikan permintaan keberkahan, keselamatan, dan kesejahteraan.

Seorang yang memimpin acara ini hendaknya betul-betul mengerti dan berpengalaman dalam melakukan turun tanahsang anak perempuan atau lakilaki agar tidak terjadi sesuatu yang tidak diinginkan dikemudian hari bagi sang anak, sehingga seorang pemimpin acarayang mengetahuiilmu dalam melakukan acara adat tersebut. Perlengkapan dan Syarat-syarat dalam Adat Turun Tanah

Sebelum acara dimulai adapun berbagai macam perlengkapan dan syaratsyaratsesaji yang pertama dalampelaksanaanadat turun tanah yang perlu disediakan adalah seperti: Nasi tumpeng lengkap. Tumpeng dengan perlengkapannya, tumpeng merupakan nasi yang dibentuk seperti kerucut yang disajikan dengan urap sayur (hidangan yang terbuat dari sayur kacang panjang, kangkung dan kecampah yang diberi bumbu kelapa yang telah dikukus) dan 
ingkung ayam. Tumpeng melambangkan permohonan orang tua kepada sang Maha Pencipta agar si anak kelak menjadi anak yang berguna, sayur kacang panjang bermakna simbol umur agar si anak berumur panjang, sayur kangkung bermakna dimanapun si anak hidup dia mampu tumbuh dan berkembang, sayur kecambah merupakan simbol kesuburan, dan ayam mengartikan kelak si anak dapat hidup mandiri. Jenang (bubur) merah dan putih.Terdiri dari jenang merah dan jenang putih yang melambangkan perjalanan hidup itu tidak selalu mulus, kadang-kadang terperosok. ${ }^{12}$ Jenang (bubur) boro-boro melambangkan bahwa anak adalah milik kedua orangtua. Jajan pasar selengkap-lengkapnya yang melambangkan dalam berkehidupan kita akan banyak berinteraksi dengan banyak orang dengan berbagai macam karakter sehingga si anak dapat mudah bersosialisasi dengan masyarakatnya. Jadah/jenang alottujuh warna. Makna yang terkandung dari jadah adalah perjalanan hidup yang akan dilalui oleh si anak.Menggambarkan kehidupan yang penuh cobaan, suka dan duka sehingga membutuhkan keuletan. Juadah tujuh macam warna melambangkan suatu harapan agar sang anak dalam setiap harinya dapat mengatasi berbagai macam kesulitan. Bunga/kembang setaman melambangkan sifat suci dalam tingkatan hidup yang akan dijalani. Menaiki tangga yang terbuat dari tebuwulung/tebu hitam melambangkan untuk menggambarkan perjalanan hidup dan mencapai cita-cita yang tinggi dan luhur. Kurungan ayam (kandang ayam) melambangkan dunia fana yang terbatas, atau suatu lingkungan masyarakat yang akan dimasukinya dengan mematuhi segala peraturan dan adat istiadat setempat. Sedangkan kurungan ayam yang dihiasi dengan berbagai macam mainan melambangkan maknanya menggambarkan dunia dengan berbagai pilihan untuk hidup di kemudian

${ }^{12}$ Lihat Heny Dwi Kurniawati, dalam http://dwikahenny24.wordpress.com/ (Online 4 Desember 2011). 
haridengan dihiasi janur kuning dan kertas warna-warni. ${ }^{13}$ Beras kuning dan kapas.Beras kuning melambangkan kelak sianak nanti akan pandai dibidang keagamaan. ${ }^{14}$ Kapas melambangkan diharapkan kelak si anak menjadi pedagang yang besar.

Beras kuning dan beberapa lembar/coin uang.Beras kuning yang dicampur dengan coin/uang logam dan bunga mawar dan melati yang melambangkan agar si anak suka menolong orang lain dengan memberikan sebagian hartanya kepada orang yang membutuhkan. Barang-barang perhiasan, antara lain: cincin, gelang, atau kalung melambangkan kelak kemudian hari si anak akan pandai mencari uang. Barang-barang yang bermanfaat, misalnya buku/pensil melambangkan sang anak kelak menjadi orang yang pandai. Bermula sang anak dimandikan dengan air gege (melambangkan harapan agar si anak dapat selalu segar dan tegar dalam menjalani hidupnya di masa depan) yang telah dicampurkan dengan bunga setaman yang bertujuanuntuk agar si anak tetapsehat, membawa nama harum bagi keluarga, mampu menjalankan kehidupan yang layak, makmur, danberguna bagi lingkungannya dalam bermasyarakat. Selanjutnya si anak berjalan menpginjak 7 jadah/jenang alot yang dibuat dengan tujuh warna sebagai lambang sang anak telah berusia 7 bulan yang menggambarkan unsur-unsur kehidupan di dunia kelak akan dilalui dan si anak akan menghadapi banyak pilihan serta dapat melalui rintangan dalam hidup. Tiap-tiap 7 warna yang terkandung dalam makna melambangkan arti sendiri, antara lain: Merah, melambangkan semangat dan keberanian; Putih, melambangkan watak dasar kesucian; Hitam, melambangkan keagungan dan keabadian; Kuning, melambangkan harapan tercapai cita-cita dan bersinar; Biru, melambangkan jati diri; Jingga, melambangkan matahari; dan Ungu, melambangkan keluhuran budi.

${ }^{13}$ Lihat Heny Dwi Kurniawati, dalam http://dwikahenny24.wordpress.com/ (Online 4 Desember 2011).

14 Ani Rosyanti dkk, Fungsi Upacara Tradisional Bagi Masyarakat Pendukungnya Masa Kini, hal. 121. 
Jadah 7 warna ini disusun mulai dari warna yang gelap ke terang, hal ini menggambarkan bahwa masalah yang dihadapi si anak mulai dari yang berat sampai yang ringan, maksudnya seberat apapun masalahnya pasti ada titik terangnya yang disitu terdapat penyelesaiannya. Jadah yang diinjak mempunyai lambang sebagai bumi tempat berpijaknya manusia dalam menjalani kehidupan. Dilanjutkan dengan naik tangga tebu wulung/tebu hitam melambangkan untuk menggambarkan perjalanan hidup dan mencapai cita- cita yang tinggi dan luhuratau bisa nggayuh kaluhuran seperti pangkat, pendidikan, dan derajat. Sehingga menandakan si anak mengenal kenyataan hidup yang akan dilalui di kemudian hari. Tangga tebu melambangkan tingkattingkat kehidupan yang mengandung harapan suatu ketetapan hati (antebing kalbu) dalam mengejar tingkatan hidup yang lebih baik. Selesai memanjat tangga tebu anak segera diturunkan kembali dan si anak diajak memasuki kedalam kurungan ayam yang telah diisi dengan berbagai macam jenis mainan.

Perspektif Hukum Islam Terhadap Adat Turun Tanah Bagi Suku Jawa di Kota Palangka Raya. Dalam hukum Islam, tradisi atau kebiasaan itu disebut dengan urf yang dapat dijadikan suatu dalil, didukung dengan salah satu dalil kaidah hukum Islam. "Adat kebiasaan dapat ditetapkan sebagai hukum."15 Kaidah ini menerangkan bahwa suatu tradisi atau adat kebiasaan di suatu daerah dapat dijadikan suatu hukum, berarti membolehkan suatu tradisi selama dalam hukumnya tidak ada dalil syara yang melarang tradisi tersebut, baik dari dalil Alquran maupun Sunnah. Padahal keberadaan tradisi-tradisi tersebut patut dilestarikan apabila tidak bertentangan dengan syari'at Islam. Sehingga segala bentuk perilaku manusia kelak akan dimintai pertanggungjawaban oleh Allah SWT. Memang ada beberapa ulama yang menyatakan segala sesuatu yang tidak pernah dilakukan oleh Rasulullah

15 Muchlis Usman, Kaidah-Kaidah Ushuliyah dan Fiqhiyah Pedoman Dasar dalam Istinbat Hukum Islam, hal. 140. 
adalah bid'ah ${ }^{16}$. Namun karena tradisi tersebut sudah turun-temurun dilakukan, mustahil untuk tidak dilakukan oleh masyarakat tersebut pada umumnya. Adapun macam-macam bid'ah ada dua, yaitu bid'ah diniyah dan duniawiyah. Bid'ah dalam masalah agama bisa di bagi menjadi empat, yaitu: Al-bid'ah al-Mukkafirah (bid'ah yang menyebabkan pengingkaran). Misalnya, berdo'a kepada selain Allah SWT, seperti kepada para Nabi dan orang shalil, meminta pertolongan kepada mereka, mohon dilepaskan dari segala kesulitan dan memenuhi hajat mereka. Al-bid'ah al-Muharramah (bid'ah yang diharamkan). Misalnya bertawassul kepada Allah SWT melalui orang yang telah meninggal, meminta do'a mereka, menjadikan kuburan mereka sebagai masjid, bernadzar menyembelih binatang untuk mereka, dan mencium kuburan mereka. Al-bid'ah al-Makruhah Tahrim (yang maksudnya adalah pengharaman). Misalnya sholat dzhuhur setelah sholat Jum'at, karena hal itu tidak disyariatkan oleh Allah SWT dan Rasul-Nya. Atau, membaca alquran dengan pamrih imbalan, bertasbih, membebaskan budak, dan khataman yang dilakukan untuk orang yang sudah meninggal. Al-bid'ah al-Makruhah Tanzih (yang maksudnya sebagai penegasan agar dijauhi). Misalnya, berjabat tangan setelah sholat, menggantungkan kain di atas mimbar, membaca do'a 'asyura', dan membaca do'a awal dan akhir tahun.

Adapun bid'ah yang berkaitan dengan kemaslahatan dunia, hukumnya boleh, selama itu bermanfaat, tidak menimbulkan kerusakan atau memancing niat jahat, tidak melanggar hal-hal yang diharamkan dan tidak merusak nilai-nilai agama. Allah membolehkan hamba-hamba-Nya melakukan kreativitas demi kemaslahatan hidup di dunia. Sebagaimana firman Allah: “Dan

16 Bid'ah artinya sesuatu yang baru dalam agama-setelah agama itu dinyatakan sempurna dan setelah wafatnya Nabi.Bentuk jamaknya adalah al-Bida' seperti kata yang sepula dengan al-'Inab.Bid'ah juga berarti sesuatu yang diciptakan namun menyalahi kebenaran yang diterima dari Rasulullah s.a.w. dan prinsip agama yang benar. Lihat Muhammad Abdussalam Khadr as-Syaqiry, Bid'ah-Bid'ah yang Dianggap Sunnah, Jakarta: Qisthi Press, 2004, hal. 3-4. 
perbuatlah kebajikan supaya kamu mendapat kemenangan.” (QS. Al-Hajj:77) Menurut Abdul Karim Zaidan, menjelaskan bahwa syarat-syarat berlakunya suatu tradisi atau kebiasaan suatu masyarakat dapat dijadikan suatu hukum adalah: Tidak ada perbedaan dalam mengamalkannya atau pada umumnya dilakukan oleh manusia yang dinyatakan dalam kaidah fiqhiyyah yang lain, yaitu sesuatu dianggap tradisi, apabila sudah berlaku atau seringkali dilakukan orang-orang. Tradisi menjadi perbandingan untuk mencapai sesuatu yang kita ingin ketahui hukumnya melalui kebiasaan yang ada sebelumnya. Tidak dianggap adat maupun tradisi apabila sesuatu yang dimaksud telah terjadi. Tradisi atau kebiasaan tersebut tidak bertentangan dengan nash atau dalil Alquran maupun Sunnah termasuk syarat yang ditetapkan antara dua orang atau lebih yang melaksanakan akad. Dalam Alquran surah Al- A'raf ayat 199 Allah berfirman:

"Jadilah Engkau Pema'af dan suruhlah orang mengerjakan yang ma'ruf, serta berpalinglah dari pada orang-orang yang bodoh”.

Kata al-'urf sama dengan kata (رعففو) ma'ruf, yakni sesuatu yang dikenal dan dibenarkan oleh masyarakat, dengan kata lain adat istiadat yang didukung oleh nalar yang sehat serta tidak bertentangan dengan ajaran agama. Ia adalah kebajikan yang jelas dan diketahui semua orang serta diterima dengan baik oleh manusia-manusia normal. Ia adalah yang disepakati sehingga tidak perlu didiskusikan apalagi diperbantahkan. ${ }^{17}$ Sedangkan kata ma'ruf dalam ayat tersebut, di mana umat manusia disuruh mengerjakannya, oleh para ulama Ushul Fiqih dipahami sebagai sesuatu yang baik dan telah menjadi kebiasaan masyarakat.Berdasarkan itu, maka ayat tersebut dipahami sebagai perintah untuk mengerjakan sesuatu yang telah dianggap baik sehingga telah menjadi tradisi dalam suatu masyarakat. ${ }^{18}$ Karena merupakan perintah, maka urf dianggap syara' sebagai dalil hukum.

\footnotetext{
${ }^{17}$ M. Shihab, Tafsir Al-Mishbah (Pesan, Kesan dan Keserasian Al-Qur'an) Volume 5, hal.353.

${ }^{18}$ Satria Effendi dan M. Zein, Ushul Fiqh, hal. 155-156.
} 
"Telah menceritakan kepada kami, Abu Bakar telah menceritakan kepada kami, Ashim menceritakan kepada kami, dari Zirr bin Hubaisy, dari Abdullah bin Mas'ud, ia berkata, "Sesungguhnya Allah melihat hati para hamba, lalu mendapati hati Muhammad SAW sebagai sebaik-baik hati para hamba, lalu memilihnya untuk diri-Nya, lalu mengutus dengan risalah-Nya, kemudian melihat hati para hamba setelah hati Muhammad, lalu mendapati hati para shahabatnya sebagai sebaik-baik hati para hamba, lalu menjadikan mereka sebagai pembantu Nabi-Nya, berperang membela agamanya. Maka, apa yang di lihat oleh kaum muslimin baik, maka sisi Allah adalah baik dan apa yang mereka lihat buruk, maka di sisi Allah juga buruk”. (HR. Ahmad)

Hadist ini mengandung pengertian, bahwa hal yang dipandang baik bagi orang-orang Islam berarti hal itu juga baik di sisi Allah yang didalamnya termasuk urf yang baik. ${ }^{19}$ Para ulama menyatakan bahwa urf merupakan salah satu sumber dalam istinbath hukum, manetapkan bahwa ia bisa menjadi dalil sekiranya tidak ditemukan nash dari Kitab (alquran) dan Sunnah (hadits). Apabila urf bertentangan dengan Kitab atau Sunnah maka urf tersebut ditolak (mardud).Sebab dengan diterimanya urf tersebut berarti mengesampingkan nash-nash yang pasti (qath'iy), mengikuti hawa nafsu dan membatalkan syariat.Karena kehadiran syariat bukan dimaksudkan untuk melegitimasi berlakunya mafasid (berbagai kerusakan dan kejahatan). Segala kegiatan yang menuju kearah tumbuh dan berkembangnya kemafsadatan harus segera diberantas, bukan malah dilegitimasi. ${ }^{20}$ Berdasarkan uraian diatas, para ulama ushul fiqih membagi urf dalam tiga macam yaitu: ${ }^{21}$ Dari segi objeknya, urf dibagi dalam: Al-urf al-lafzhi (kebiasaan yang menyangkut ungkapan) adalah kebiasaan masyarakat dalam mempergunakan lafal/ungkapan tertentu untuk mengungkapkan sesuatu, sehingga makna ungkapan itulah yang dipahami dan terlintas dalam pikiran masyarakat. Al-urf al-amali (kebiasaan yang

\footnotetext{
${ }^{19}$ Muchlis Usman, Kaidah-Kaidah Ushuliyah dan Fiqhiyah: Kaidah-Kaidah Istinbath Hukum Islam, hal. 141.

${ }^{20}$ Muhammad Abu Zahrah, Ushul Fiqh, Jakarta: Pustaka Firdaus, 2007, hal. 418.

${ }^{21}$ Khairul Umam, dkk. Ushul Fiqih I, hal. 160-163.
} 
berbentuk perbuatan) adalah kebiasaan masyarakat yang berkaitan dengan perbuatan biasa atau muamalah keperdataan.

Dari segi cakupannya, urf terbagi dua yaitu: Al-urf al-am (kebiasaan yang bersifat umum) adalah kebiasaan tertentu yang berlaku secara luas di seluruh daerah. Al-urf al-khas (kebiasaan yang bersifat khusus) adalah kebiasaan yang berlaku di daerah dan masyarakat tertentu. Dari segi segi keabsahannya dari pandangan syara', urf terbagi dua yaitu: Al-urf al-sahih (kebiasaan yang dianggap sah) adalah kebiasaan yang berlaku di tengah-tengah masyarakat yang tidak bertentangan dengan nash (ayat dan hadis), tidak menghilangkan kemaslahatan mereka, dan tidak pula membawa mudarat bagi mereka. Al-urf alfasid (kebiasaan yang dianggap rusak) adalah kebiasaan yang dengan dalil-dalil syara dan kaidah-kaidah dasar yang ada dalam syara' bertentangan.

Pada dasarnya, sebagian ulama ada yang berpendapat bahwa segala sesuatu yang tidak pernah dilakukan oleh Nabi Muhammad SAW adalaha bid'ah dan urf tidak dapat dijadikan sebagai dalil dalam menetapkan suatu hukum.Dalam kitabnya Imam Syafi'I berkata, bahwa hukum dasar pelarangan Rasulullah SAW adalah bahwa semua larangan itu adalah haram sampai ditemukannya dalil yang menyatakan bahwa beliau melarang perkara itu suatu selain haram.Seperti hendak melarang sebagian perkara saja, atau larangan itu bertujuan membimbing untuk meninggalkan perbuatan yang rendah dan mengerjakan yang lebih utama (tanzih) atau bimbingan tata krama maupun pemberian pilihan. Kita tidak membedakan larangan Rasulullah SAW kecuali berdasarkan keterangan dari beliau sendiri, atau berdasarkan perkara yang tidak diperselisihkan oleh kaum muslimin tidak mungkin tahu Sunnah, meskipun sebagian mereka mungkin tidak mengetahuinya. 


\section{E. Kesimpulan}

Berdasarkan hasil penelitian yang telah penulis lakukan mengenai Adat Turun Tanah Bagi Suku Jawa di Kota Palangka Raya Ditinjau dari Perspektif Hukum Islam, maka penulis dapat mengambil kesimpulan sebagai berikut: Prosesi pelaksanaan adat turun tanah adalah suatu tradisi rangkaian prosesi kelahiran yang dilakukan terus-menerusdari nenek moyang mereka yang mana tradisi ini pun sudah ada sejak zaman dahulu, hal ini dilakukan guna menganggap tradisi ini sebagaiuntuk pelestarikan budaya dan menjaga kebudayaan suku Jawa dalam lingkungan masyarakat Jawa terdapat berbagai macam adat yang bahwa tata cara adat istiadat merekamengandung do'a-do'a dan harapan orangtua, keluarga, dan masyarakat. Sedangkan pelaksanaan prosesi acaranya dilakukan dengan beberapa hal penting. Pertama, sang anak akan di bimbing oleh ke dua orangtuanya untuk menginjakkan kakinya ke 7 jadah/jenangalot. Kedua,sang anak akan menaiki tangga tebu wulung/tebu hitam. Ketiga, diteruskan dengan sang anak memasuki ke dalam kurungan ayam (kandang ayam) dengan memilih beberapa jenis mainan yang telah disediakandi dalam kurungan ayam tersebut, dengan mengundang beberapa masyarakat setempat atau kerabat dekat.Sehingga bahkan inti dari sarana dilakukan turun tanah ini sebagai bentuk upaya memberikan gambaran minat dan bakat dalam kehidupan yang berhubungan dengan manusia dan Allah SWT yang dilandaskan agar senantiasa diberikan wujud keselamatan, perlindungan, ketentraman, dan kesejahteraan dalam hidup.

\section{Daftar Pustaka}

Arifin, Miftahul, dan A. Faishal Hag, Ushul Fiqih: Kaidah-Kaidah Penetapan HukumIslam, Surabaya: Citra Media, 1997.

Arikunto, Suharsimi, Prosedur Penelitian Suatu Pendekatan Praktek, Jakarta: Rineka Cipta, 1997.

Az-Zuhaili, Wahbah, Fiqih Islam Wa Adillatuhu Jilid 1, Jakarta: Gema Insani, 2010. 
Chafidh, M. Aftan dan A. Ma'ruf Asrori, Tradisi Islam (Panduan Prosesi Kelahiran-Perkawinan-Kematian), Surabaya: Khalista, 2006.

Djazuli, A., dan I. Nurol Aen, Ushul Fiqh, Jakarta: PT RajaGrafindo Persada, 2000.

Djazuli, A., Kaidah-Kaidah Fikih: Kaidah-Kaidah Hukum Islam Dalam Menyelesaikan Masalah-Masalah Yang Praktis, Jakarta: Kencana Prenada Media Group, 2007

Effendi, Satria, dan M. Zein, Ushul Fiqh, Jakarta: Kencana Prenada Media Group, 2008.

Moleong, Lexy, Metodologi Penelitian Kualitatif, Surabaya : Angkasa, 2001.

Mudjib, Abdul, Kaidah-Kaidah Ilmu Fiqih, Jakarta: PT. Kalam Mulia, 2001. Musbikin, Imam,

Rosyanti dkk, Ani, Fungsi Upacara Tradisional Bagi Masyarakat Pendukungnya Masa Kini, Yogyakarta: Departemen Pendidikan dan Kebudayaan, 1994.

Shihab, M. Quraish, Tafsir Al-Mishbah (Pesan, Kesan dan Keserasian AlQur'an) Volume 1, Jakarta: Lentera Hati, 2002.

Tim Penyusun Departemen Pendidikan dan Kebudayaan, Kamus Besar Bahasa Indonesia, Jakarta: PT Balai Pustaka, 1988.

Tim Penyusun, Pedoman Penulisan Skripsi, Palangka Raya: STAIN, 2007.

Tim Redaksi Departemen Pendidikan Nasional, Kamus Besar Bahasa Indonesia, Jakarta: PT Balai Pustaka, 2005.

Umam, Khairul, dkk. Ushul Fiqih I, Bandung: CV Pustaka Setia, 2000.

Usman, Muchlis, Kaidah-Kaidah Istinbath Hukum Islam (Kaidah-Kaidah Ushuliyah dan Fiqhiyah), Jakarta: PT RajaGrafindo Persada, 1999. 